\title{
HISTOPATHOLOGICAL EFFECTS OF Spodoptera littoralis NPV ON THE LARVAL MIDGUT OF THE COTTON LEAFWORM, Spodoptera littoralis (BOISD.) \\ El-Banna, A. A. ${ }^{\text {; }}$ Sara M. I. Abd El-Kareem ${ }^{2}$; A. S.El-Akad'; M. A Hussein ${ }^{1}$; A. R. Fahmy ${ }^{1}$ and H. K. Bekheit ${ }^{2}$ \\ 1. Dept. of Entomology, Faculty of Science, Ain Shams University, Cairo. \\ 2. Plant Protection Research Institute, Dokki, Giza.
}

\begin{abstract}
The histopathological effects of the commercial product Viruset ${ }^{\circledR}$ (based on Spodoptera littoralis NPV) on the larvae of the cotton leaf worm, were investigated in the laboratory. Treatment of the $4^{\text {th }}$ instar larvae with the bioinsecticide revealed many ultrastructural alterations in the midgut of the $6^{\text {th }}$ instar larva. This is evident in the apparent alterations as in the cytoplasm, the nuclei, and chromatin. The use of this biocontrol agent is therefore quite promising against this pest.

Keywords: Bioinsecticides, cotton leafworm, ultrastructure, histopathology, Spodoptera littoralis NPV.
\end{abstract}

\section{INTRODUCTION}

The cotton leafworm Spodoptera littoralis (Boisd.) is a major cotton pest in Egypt attacking economically important crops all year round. It is considered highly destructive due to its high reproductive rate.

Chemical control of $S$. littoralis has been extensively used especially on cotton which has led to development of resistance to these compounds. Since then, synthetic pyrethroids, insect growth regulators and other nonconventional insecticides have been used, with many reports of resistance and cross resistance development in many cases (Issa et al., 1984 a and b; and Abo-El-Ghar et al., 1986). The unwise use of synthetic insecticides gives rise to high resistance to many chemical pesticides, resurgence, and residues of chemical pesticides in the environment (Forgash, 1984 and Georghiou, 1986). More attention should be paid to the use of bioinsecticides such as compounds based on bacteria, fungi, and viruses (Rao et al., 1990). These groups have unique modes of action (Asher, 1993 and Thompson et al., 1999) and their properties may differ considerably from the conventional agents with which growers are familiar.

The aim of this research was to study the histopathological effects of the commercial product Viruset ${ }^{\circledR}$ (based on Spodoptera littoralis NPV) on the larvae of the cotton leafworm.

\section{Rearing Technique:}

\section{MATERIALS AND METHODS}

A laboratory susceptible strain of the cotton leafworm, Spodoptera littoralis (Boisduval) (Lepidoptera: Noctuidae) reared in the laboratory for 
more than 10 generations, was obtained as egg masses from the Research Division of the cotton leafworm, Plant Protection Research Institute, DokkiGiza, Egypt.

Insects were reared in an incubator under controlled conditions at $26 \pm$ $2^{\circ} \mathrm{C}$ and $65 \pm 10 \%$ R. H., with 8:16 L:D photoperiod (El-Sawaf, 1971) at the Plant Protection Research Institute.

Larval jars were supplied daily with fresh Castor leaves, Ricinus communis L., as a source of food.

The test bioagent:

The commercial bioinsecticide Viruset ${ }^{\circledR}$ WP $4 \%$ was used in this investigation. It is based on (Spodoptera littoralis nucleopolyhedrosis virus [SplNPV]). Spodoptera littoralis NPV was isolated from diseased larvae. It was obtained as a wettable powder produced by the Plant Protection Research Institute, Biopesticide Production Unit, Dokki- Giza, Egypt.

\section{Specimen treatment and preparation:}

Larvae were treated as fourth instar with $L_{50}$ of Viruset $^{\circledR}$ at a concentration of $1 \times 10^{-4} \mathrm{gm} / \mathrm{ml}$ according to Abd El-Kareem et al. (2010). Treated larvae were dissected in the late $6^{\text {th }}$ instar and prepared for Transmission Electron Michrograph. Preparation and ultrascan micrograph were carried out at the Military Medical Research Unit, Abassia, Cairo, Egypt.

Midguts from the larvae were dissected and immediately fixed in $2.5 \%$ glutaraldehyde at $4^{\circ} \mathrm{C}$, for 3 days. The midguts were then washed in $0.1 \mathrm{M}$ buffer, fixed in $2 \%$ osmium tetroxide in $0.2 \mathrm{M}$ buffer solution for one hour then rinsed in $0.2 \mathrm{M}$ buffer. The specimens were dehydrated by ethanol series dehydration. They were then added to Propylene oxide and transferred to eponate epoxy. Finally the specimens were embedded in labeled capsules with freshly prepared resin and polymerized at $60^{\circ} \mathrm{C}$ for 48 hours. The $\mathrm{pH}$ was kept within the range $7.2-7.4$.

Ultrathin section preparation:

Ultrathin sections of the resin embedded specimens were obtained using an ultracut E microtome. Sections for TEM analysis were collected on carbon coated formvar supports, stained with uranyl acetate and lead citrate (Reynolds, 1963) and examined in a SEM electron microscope equipped with a ProScan slow scan CCD camera.

\section{RESULTS AND DISCUSSION}

\section{Normal midgut ultrastructure of untreated larvae of the cotton leafworm:}

The midgut epithelial ultrastructure of untreated larvae of $S$. littoralis is presented in figures 1-4. The normal lining epithelium of the midgut consists of columnar cells resting on a basement membrane with an oval centrally located nucleus bound by a well defined nuclear envelope. The cytoplasm is clear. Patches of varying densities of nuclear chromatin are visible (Fig. 1).

Figure (2) shows the normal epithelial cells. The continuous integrated brush border characterizes the midgut epithelium of the normal larval midgut. 
The Lumen and microvilli are observed. The presence of some secretory vesicles is also recognized. Microvilli project inwards from the luminal surface of the epithelial cells into the luminal cavity. The Golgi's appear as flattened curved sacs with cluster bodies at their edges (Fig. 3).

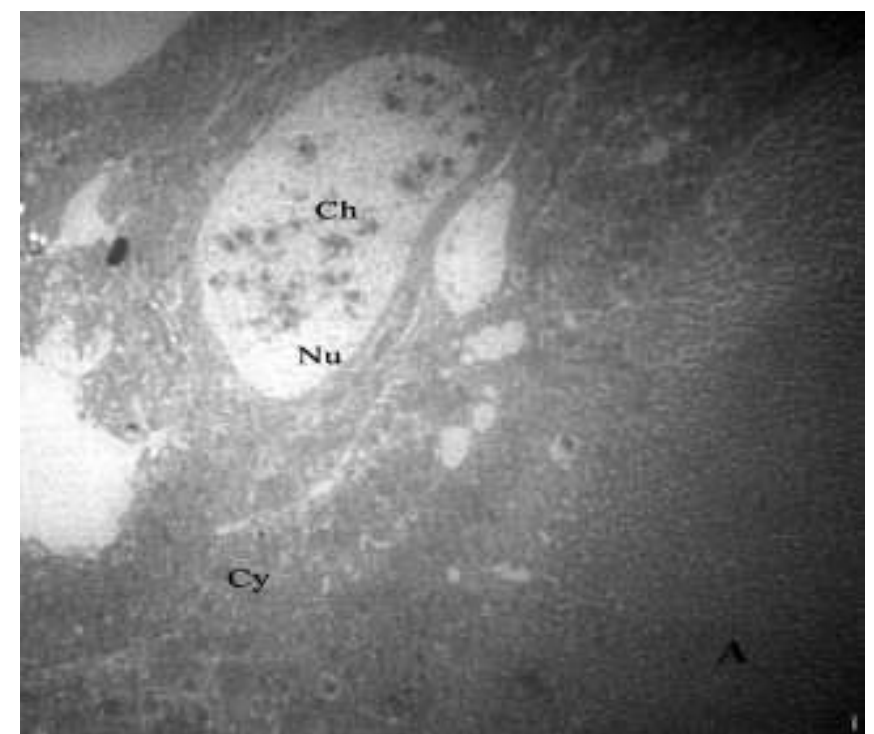

Fig. (1): Transmission electron micrograph of the midgut of the late $6^{\text {th }}$ instar larva of Spodoptera littoralis showing the normal epithelial cell. Cytoplasm (Cy), Nucleus (Nu), Chromatin material (Ch) (x1500)

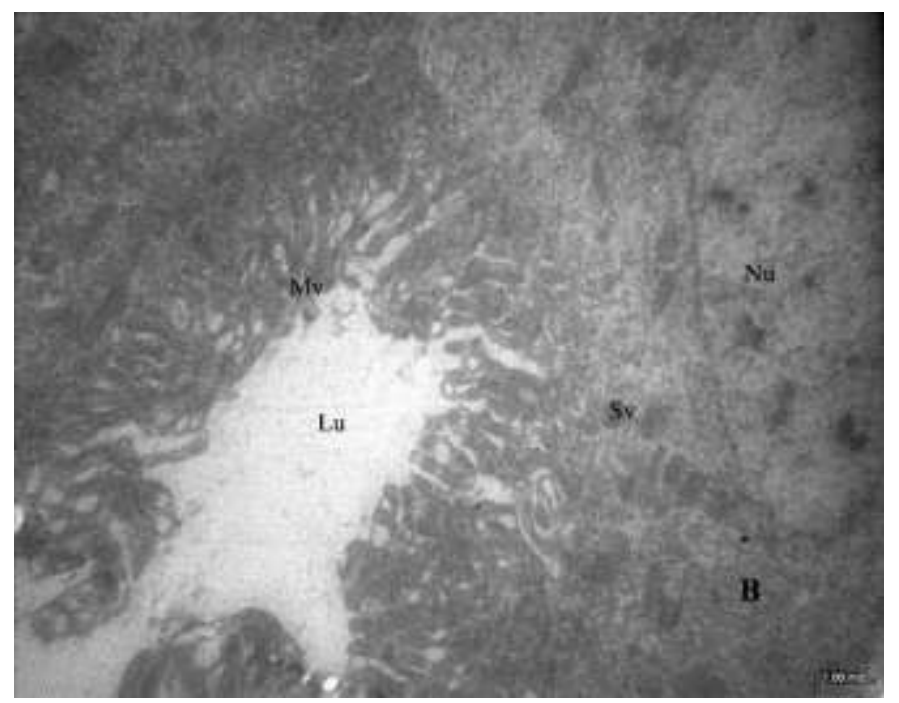

Fig. (2): Transmission Electron micrograph of the midgut of the late $6^{\text {th }}$ instar larva of Spodoptera littoralis showing the normal epithelial cell. Brush border (arrow). Lumen (Lu), microvilli (Mv), Secretory vesicles (Sv) (x3000). 


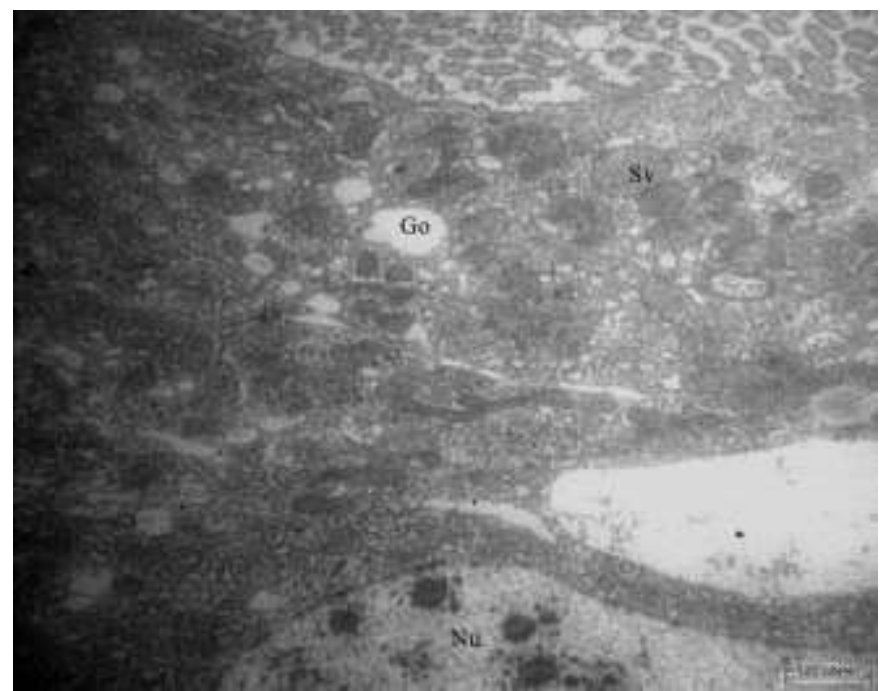

Fig. (3): Transmission electron micrograph of normal epithelial cell of the midgut of the late $6^{\text {th }}$ instar larva of $S$. littoralis. Secretory vesicles (Sv), Golgi apparatus (Go) (x6000).

The outer surface of the cell rests on the basement membrane. Within the cytoplasm lie the more or less elongated or spherical shaped mitochondria. Lamellated rough and smooth endoplasmic reticula can be observed with Ribosomes bordering the outer surface of the rough endoplasmic reticulum (Fig.4).

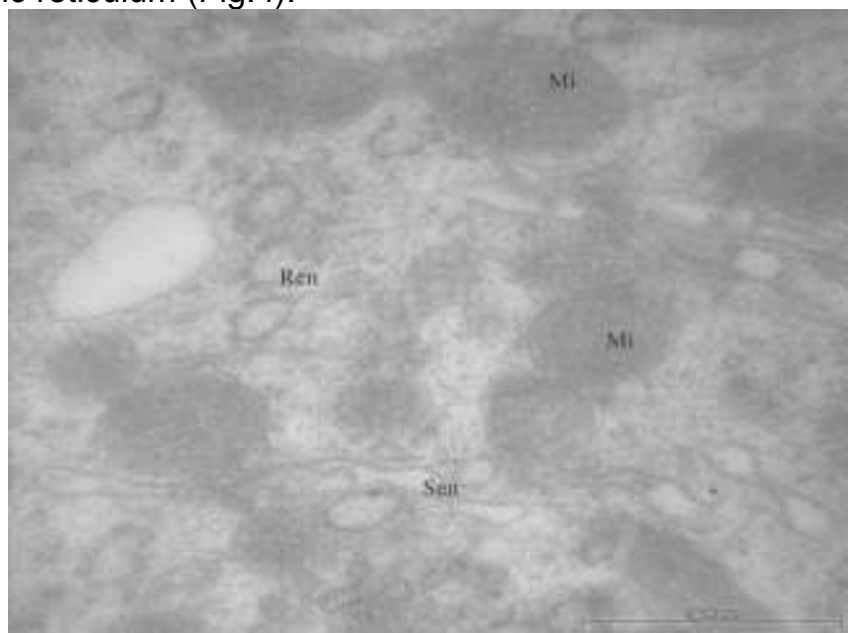

Fig. (4): Transmission electron micrograph of normal midgut of the late $6^{\text {th }}$ instar larva of $S$. littoralis showing the presence of many normal mitochondria (Mi). Rough endoplasmic reticulum (Ren) with ribosomes attached to its surface. Smooth endoplasmic reticulum (Sen). (x20,000). 
Histopathological effect of the nuclear polyhedrosis virus (Sp/iNPV) on the larval midgut:

The histopathological effects of Sp/NPV infection on the epithelial cells of the midgut of late $6^{\text {th }}$ instar larvae of the cotton leafworm treated as $4^{\text {th }}$ instar larvae, are shown in Figs. (5-9).

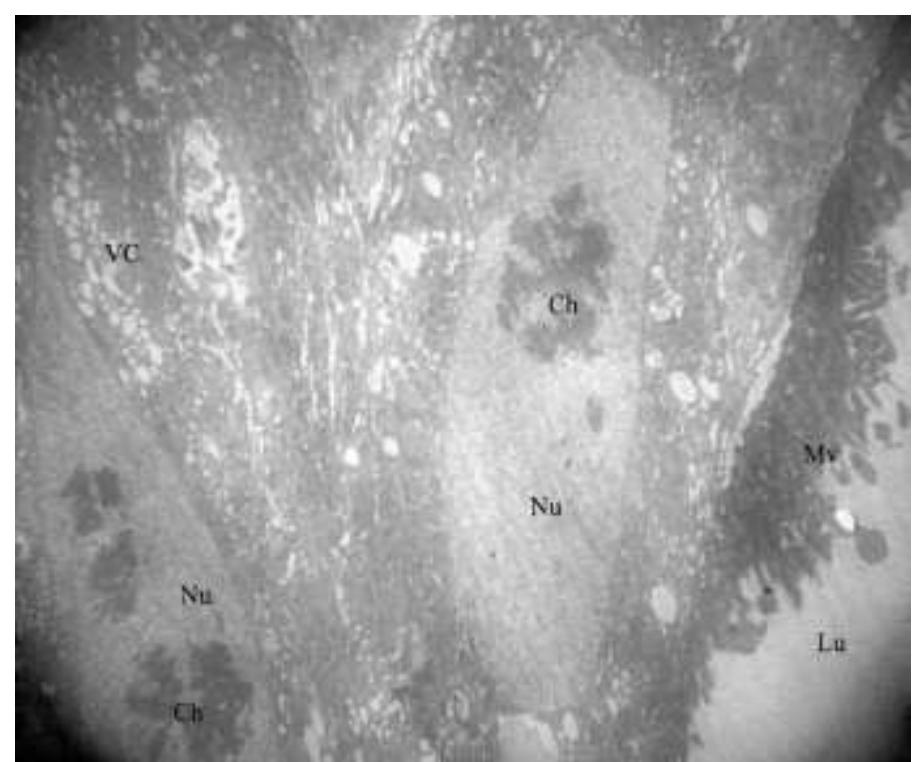

Fig. (5): Transmission electron micrograph of the midgut of the late $6^{\text {th }}$ instar larva of $S$. littoralis treated with $\mathrm{LC}_{50}$ of Sp/NPV. The nucleus (Nu). The chromatin material (Ch). The microvilli (Mv). The gut lumen (Lu). The vacuolization of the cytoplasm (VC) (x2000).

The first signs of infection were a rounding of the cell and a more granular and dense appearance of the cytoplasm

The nucleus stretched and the chromatin material became condensed and scattered. The centrally located nucleolus disappeared and heterochromatin accumulated along the inner margins of the nuclear envelope. Vacuolization of the cytoplasm is visible (Fig. 5). The microvilli became swollen and separated into the gut lumen (Fig. 5 \& 6).

The brush border separated from the cell border and the vacuolated cytoplasm appeared (Figs. 6). The chromatin became condensed and scattered and transporter vesicles containing virus occlusion bodies appeared beside the nuclear membrane (Fig. 7).

The nucleus appeared to be hypertrophic and distinct regions of heterochromatin throughout the nucleus were formed. The nuclear membrane remained intact. In addition, transporter vesicles that contain OB's were observed (Fig.7). The order and orientation of the brush border were 
lost (Figs.6 \& 7). Complete loss of the brush border observed. Microvilli are swollen and broken into gut lumen (fig. 8).

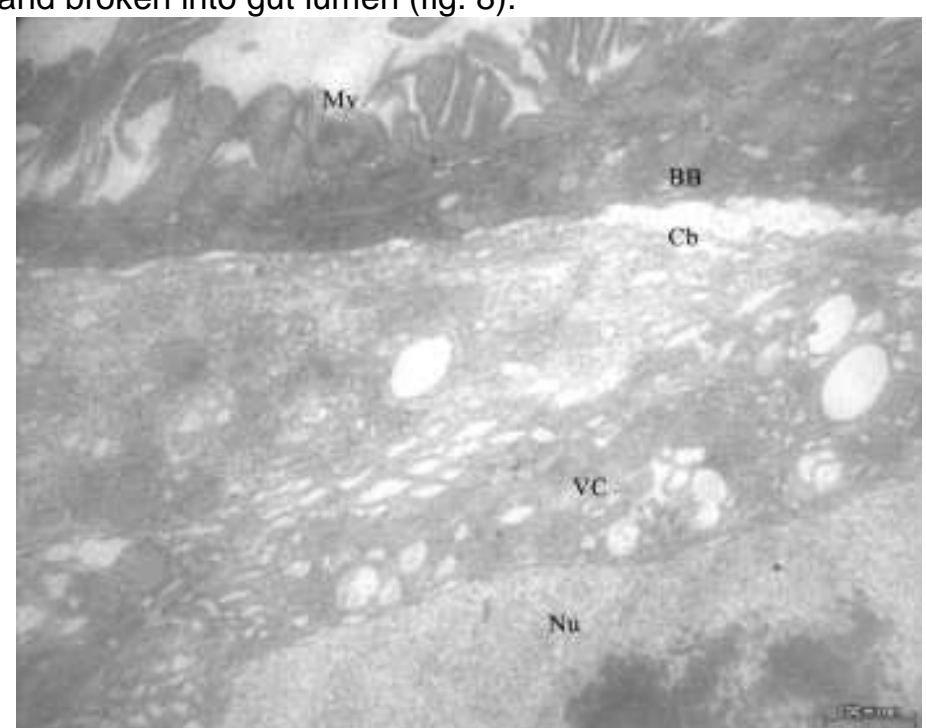

Fig. (6): Transmission Electron micrograph of the midgut of the late $6^{\text {th }}$ instar larva treated with $\mathrm{LC}_{50}$ of Sp/NPV. The microvilli (Mv) are swollen and disintegrated. The brush border (BB) is separated from cell border (CB); vacuolated cytoplasm is visible (VC) (x6000).

Fig. (7): Transmission Electron micrograph of the midgut of the late $6^{\text {th }}$ instar larva treated with LC $_{50}$ of Sp/NPV. The chromatin (Ch) is condensed and scattered. Transporter vesicles (TV) containing virus occlusion bodies (arrow) are visible beside the nuclear membrane (NuM) (x15000) 


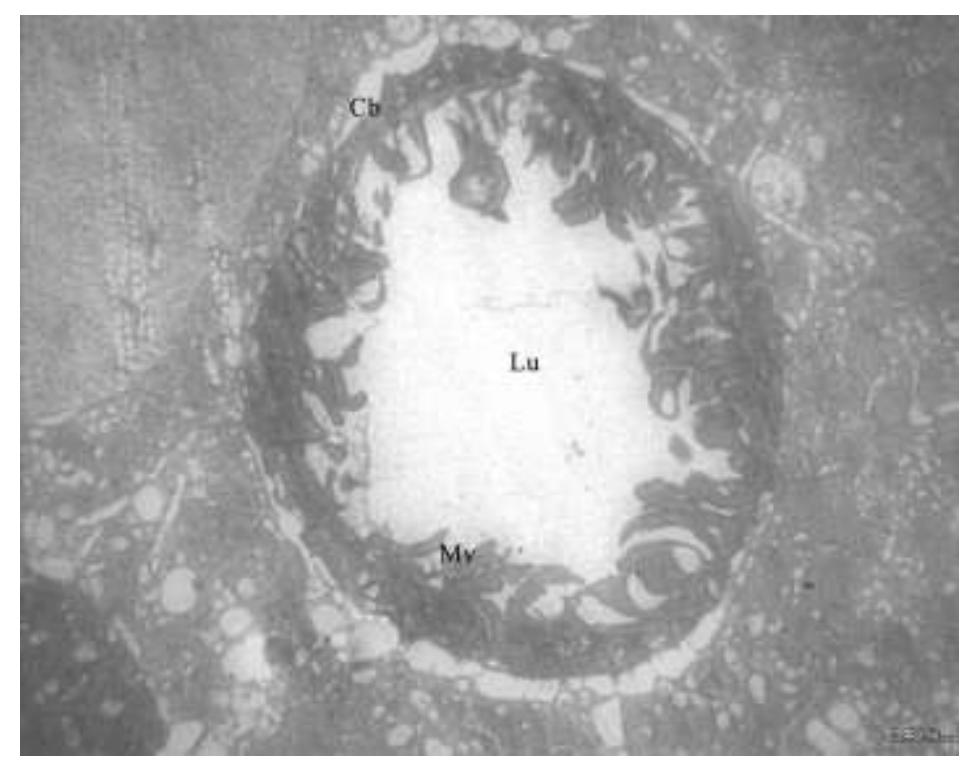

Fig. (8): Transmission Electron micrograph of the midgut of the late $6^{\text {th }}$ instar larva treated with $\mathrm{LC}_{50}$ of Sp/NPV. Complete loss of the brush border observed. Microvilli (Mv) are swollen and broken into gut lumen (Lu). Cell border (Cb) (x3000).

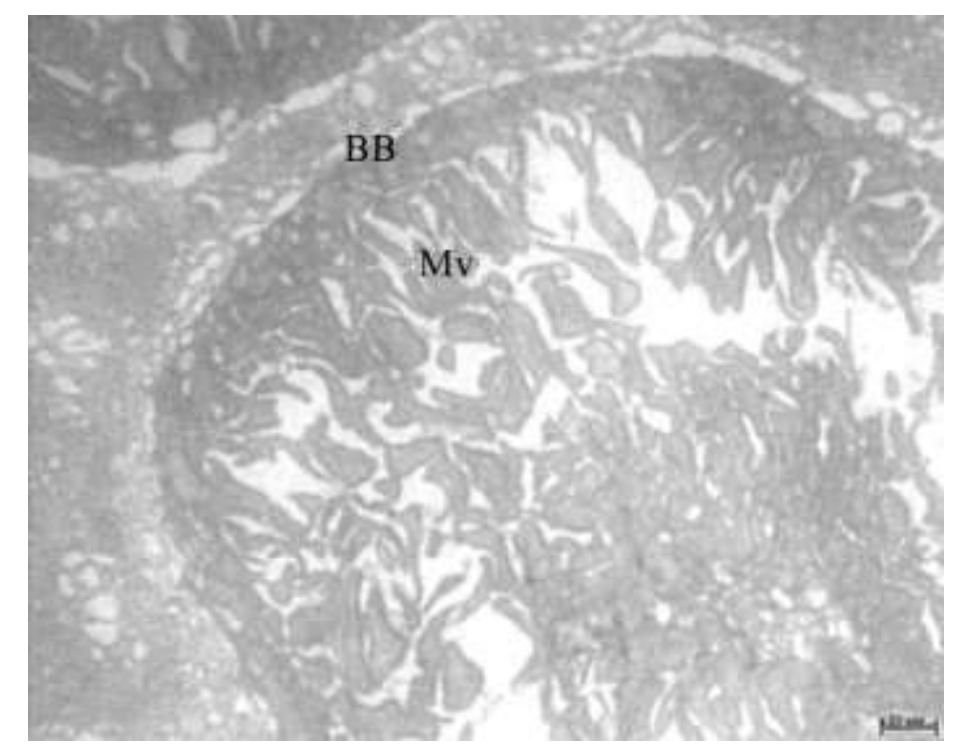

Fig. (9): Transmission Electron micrograph of the midgut of the late $6^{\text {th }}$ instar larva treated with LC $_{50}$ of SpliNPV. The cell brush border (BB) is separated from the cell and the microvilli (Mv) appeared more destructed $(\times 3000)$. 
The microvilli were destructed and separated into gut lumen (Fig. 9). The cell brush border was separated from the cell and the microvilli appeared more destructed].

One important aspect to be considered is that normal or physiological cell death occurred in most insect gut epithelium. Indeed, Wyllie et al. (1984) have proposed that cell death is frequently controlled by normal homeostatic regulation although it may be induced in cells following relatively minor injury by non-physiological or toxic stimuli. These histopathological changes were reported in details in Moser et al. (2001); Sakr and Hassab El-Nabi (2007); Abdel-Aziz (2007); Abd-El Wahed et al. (2011); and Abd El-Kareem (2012). The use of the commercial product Viruset ${ }^{\circledR}$ is quite promising against $S$. littoralis.

\section{REFERENCES}

Abd El-Kareem, S. M. I. (2012). Effect of some entomopathogens and insecticides against the cotton leafworm, Spodoptera littoralis (Boisduval) (Lepidoptera: Noctuidae). Ph. D. Thesis. Fac. Sci. Ain Shams Univ. Pp. 185.

Abd El-Kareem, S. M. I.; El-Akad, A. S.; Hussein, M. A.; El-Banna, A. A.; Fahmy, A. R.; and Bekheit, H. K. (2010). Effect of interaction of bioinsecticides and a carbamate insecticide on the larvae of the cotton leafworm, Spodoptera littoralis (Boisd.), by successive applications. Egyptian academic Journal of Biological Science, 3(2): 11-17.

Abd-El Wahed, M. S.; Ahmed, F. M.; Abdel-Aal, A. E.; and Abdel-Aziz, M. M. (2011). The effect of certain biocontrol agent on some biological, biochemical and histological aspects of the cotton leafworm Spodoptera littoralis (Boisd.) (Lepidoptera: Noctuidae). Egyptian journal of agricultural research, 89(2): 431-444.

Abdel-Aziz, M. M. M. (2007). Controlling of the cotton leafworm, Spodoptera littoralis (Boisd.), by using environmentally safe (nontraditional) methods. M. Sc. Thesis, Inst. Environmental Studies and Research, Ain Shams Univ.

Abo-El-Ghar, M. R.; Nassar, M. E.; Riskalla, M. R.; and Abd-El-Ghafar, S. F. (1986). Rate of development of resistance and pattern of crossresistance in fenvelerate and decamethrin-resistant strains of Spodoptera littoralis. Agricultural Research Review, 61:141-145.

Asher, K. R. S. (1993). Nonconventional insecticidal effects of pesticides available from the Neem tree, Azadirachta indica. Archives of Insect Biochemistry and Physiology, 22(3-4): 433-449.

El-Sawaf, B. M. (1971). Effect of some chemical insecticides on the reproductive system and reproduction in the cotton leafworm Spodoptera littoralis, Boisd. (Prodenia litura). Ph. D. Thesis. Fac. Sci. Ain Shams Univ.

Forgash, A. J. (1984). History, evolution and consequences of insecticide resistance. Pesticide biochemistry and physiology, 22:178-186. 
Georghiou, G. P. (1986). The magnitude of the resistance problem. p. 14-43. In: "Pesticide Resistance: Strategies and Tactics for Management". National Academy Press, Washington, D.C.

Issa, Y. H.; Keddis, M. E.; Abdel-Sattar, M. A.; Ayad, F. A.; and El-Guindy, M. A. (1984a). Survey of resistance to organophosphorus insecticides in field strains of the cotton leaf-worm during 1980-1984 cotton-growing seasons. Bull. Entomol. Soc. Egypt, Economic Series, 14:399-404.

Issa, Y. H.; Keddis, M. E.; Abdel-Sattar, M. A.; Ayad, F. A.; and El-Guindy, M. A. (1984b). Survey of resistance to pyrethroids in field strains of the cotton leaf-worm during 1980-1984 cotton growing seasons. Bull. Entomol. Soc. Egypt, Economic Series 14: 405-411.

Moser, B. A.; Becnel, J. J.; White, S. E.; Afonso, C.; Kutish, G.; Shanker, S.; and Almira, E. (2001). Morphological and molecular evidence that Culex nigripalpus baculovirus is an unusual member of the family Baculoviridae. Journal of general virology, 82(pt2): 283-297.

Rao, N. V.; Reddy, A. S.; and Reddy, P. S. (1990). Relative efficacy of some new insecticides on insect pests of cotton. Indian journal of plant protection, $18(1)$ : 53-58.

Reynolds, E. S. (1963). The use of lead citrate at high pH as an electronopaque stain in electron microscopy. Journal ofcell biology, 17(1): 208212.

Sakr, H. H. and Hassab El-Nabi, S. E. (2007). Histological and nucleic acid alterations in Spodoptera littoralis (Boisd.) (Lepidoptera: Noctuidae) induced by Streptomyces lavendulae (Streptomycetaceae) culture filtrate. Egyptian journal of biology, 9: 32-41.

Thompson, G. D.; Hutchins, S. H.; and Sparks, T. C. (1999). Development of spinosad and attributes of a new class of insect control products. University of Minnesota. Available at: http://www.ipmworld.umn.edu/chapters/hutchins2.htm

Wyllie, A. H.; Durall, E.; and Blow, J. I. (1984). Intracellular membrane in cell death in normal and pathological tissues. In: Davies, I. and Sigee, D. C. Cell ageing and cell death. Cambridge Press, Pp. 269-294. 
التأثيرات الهيستوباثولوجية للفيروست على المعى المتوسط ليرقات دودة ورق

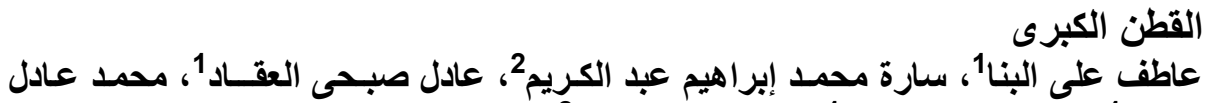

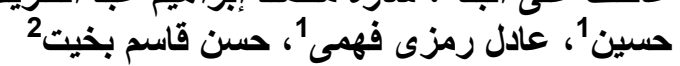

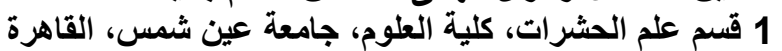
2 معهد بحوث وقاية النباتات، الدقى، الجيزة

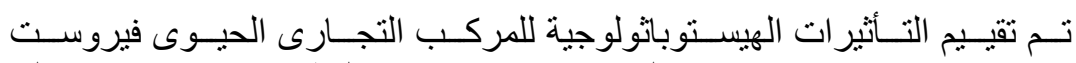

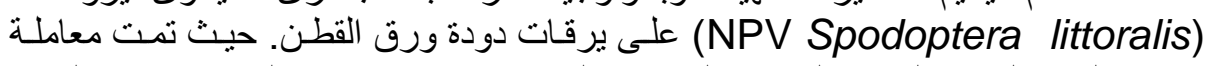

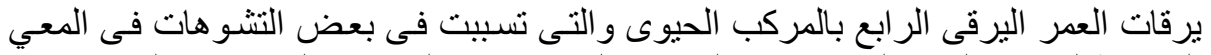

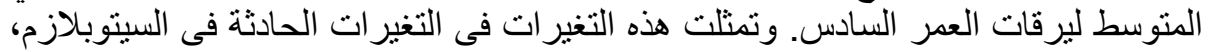

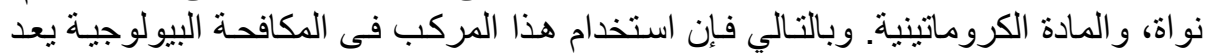
طريقة واعدة جدا ضد هذه الآفة.

كلية الزراعة - جامعة المنصورة قام بتحكيم البحث

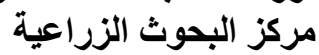

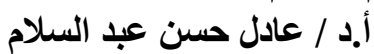
أ.د /سندس عبد التواب محمد حسين العلام حسن 